\title{
Stratification of Bitterbrush Seeds
}

\section{JAMES A. YOUNG AND RAYMOND A. EVANS}

Highlight: The influence of temperature and moisture availability during stratification on the subsequent germination of bitterbrush (Purshia tridentata) seeds was investigated. The threshold for adequate stratification temperatures was abrupt. Temperatures above $5^{\circ} \mathrm{C}$ were too warm and below $0^{\circ} \mathrm{C}$, too cold for stratification; $2^{\circ} \mathrm{C}$ was optimum for the longest duration. Prolonged stratification resulted in decreased viability, apparently from microbial activity and early germination. Stratification in osmotic solutions produced with polyethylene glycol was totally ineffective. Soil water stress reduced the effectiveness of stratification, especially with sand as a substrate. Any departure from optimum temperature and moisture regimes prolonged the time required for stratification or negated any effect of the stratification treatment.

The authors are range scientists, Agricultural Research Service, U.S. Department of Agriculture, University of Nevada, Renewable Resources Center, Reno 89512 .

The study involved cooperative investigation of the Agr. Res. Serv., U.S. Dep. Agr., and the Agricultural Experiment Station, Univ. of Nevada, Reno. Journal Series No. 306.

The authors wish to thank Drs. E. C. Nord, R. O. Meeuwig, and P. J. Umess for the helpful suggestions in reviewing this manuscript.

Manuscript received December 18, 1975.
Researchers have made numerous studies in several western states to find ways of seeding bitterbrush (Purshia tridentata) to revegetate degraded rangelands (Nord, 1957). One hindrance to seeding is dormancy of bitterbrush seed (Pearson, 1957). Mirov and Kraebel (1937) made initial contributions to our knowledge of the germi- nation characteristics of bitterbrush, but the germination ecology of bitterbrush is still largely a mystery.

Dormancy in bitterbrush can be broken by overwintering in the soil (Hormay, 1943), artificial stratification (Mirov and Kraebel, 1937), or soaking in a solution of thiourea (Pearson, 1957). Fall planting is thought to provide the overwintering that naturally breaks the seed dormancy, but spring planting is often desirable to avoid rodent and frost-heaving damage (Hubbard, 1958). Stratified seeds are often too soft and moist (sticky) for spring planting with mechanical equipment unless it is mixed with vermiculite or rice hulls. Stratified seeds must be kept from drying and must be seeded in 
moist soil (Nord and Knowles, 1958).

Thiourea has been hailed as the ideal preplanting seed treatment for bitterbrush because it leaves the seeds dry and entirely suitable for planting with mechanical equipment (Pearson, 1957). Field tests on the emergence of thioureatreated seeds have provided variable results (Hubbard, 1958). Part of this variability is probably due to differential leaching of thiourea from the seeds in the seedbed.

The labeling of thiourea as a carcinogenic material, confusion over federal and state registration requirements for seed treatments of dormancy, and regulations within some land-management agencies have limited the use of this dormancy-breaker on bitterbrush.

Thiourea is not sold as a seed treatment material, and treated seeds never enter commercial markets. Land managers buy thiourea that is manufactured for industrial use and treat their own seeds before planting. The industrial thiourea is labeled as producing cancer in animals. There is no threshold dosage for humans established. As far as we know, no one has ever determined if handling thiourea-treated seeds presents any danger to human health.

This leaves land managers in a difficult position. Either they must forego spring seeding because of lack of natural stratification of nonthiourea-treated seeds, or they must expect early spring seeding to provide sufficient stratification. Obviously, they need detailed information on the nature of the stratification requirements of bitterbrush seeds and how less than ideal temperature and moisture conditions influence stratification requirements.

Our purpose was to investigate the influence of temperature and moisture availability during stratification on the subsequent germination of bitterbrush seeds.

\section{Methods}

We collected bitterbrush seeds near Truckee, Calif., and Granite Peak, north of
Table 2. Germination temperature $\left({ }^{\circ} \mathrm{C}\right)$.

\begin{tabular}{cccccccccc}
\hline & \multicolumn{10}{c}{ Weeks of stratification } \\
\cline { 2 - 10 } Temperature & 1 & 2 & 3 & \multicolumn{1}{c}{4} & 5 & 6 & 7 & 8 & 12 \\
\hline 10 & 0 & 8 & 8 & 10 & 16 & 22 & 12 & 2 & 0 \\
8 & 0 & 6 & 8 & 8 & 10 & 12 & 16 & 8 & 0 \\
5 & 0 & 0 & 5 & 5 & 8 & 10 & 12 & 8 & 0 \\
2 & 0 & 0 & 0 & 2 & 4 & 6 & 5 & 2 & 0 \\
0 & 0 & 0 & 0 & 0 & 2 & 0 & 0 & 2 & 0 \\
-2 & 0 & 0 & 0 & 0 & 0 & 0 & 0 & 0 & 0 \\
\hline
\end{tabular}

'Mean of six lots of seed.

Reno, Nev., in 1971 and 1973 (Table 1). Seed production was insufficient in 1972 for collection. In addition, we used commercially obtained seeds from both years. The commercial seed was a mixture from many sources.

The locally collected sources were placed in the stratification test 2 months after maturity. The commercially obtained sources were tested at the same time, but they were produced at least a year earlier. We used 4 replications of 100 seeds per replication in all experiments.

\section{Stratification-Temperature and Duration}

We placed plump, undamaged bitterbrush seeds between germination blotters in petri dishes. Blotters were used instead of sand, so that the seeds could be readily examined during stratification. We moistened the blotters with water and placed stratification dishes in dark germinators. Care was taken to insure the blotters were moist, but not submerged in water. Temperature regimes were $-4,-2,0,2,5,8$, and $10^{\circ} \mathrm{C}$ for $1,4,5,7,10$, and 14 days and weekly intervals through 12 weeks. A coldtemperature gradient bar (Evans et al., 1970) was used for the $-4,-2$, and $0^{\circ} \mathrm{C}$ temperatures. The dark germinators maintained constant temperatures at $\pm 1.0^{\circ} \mathrm{C}$, and the cold bar at $\pm 0.5^{\circ} \mathrm{C}$.

After stratification, seeds that had germinated were counted. The plates were transferred to a $15^{\circ} \mathrm{C}$ dark germinator, from which germinating seedlings were removed weekly through 4 weeks. Seeds with white, apparently healthy radicles emerged $5 \mathrm{~mm}$ were considered germinated. The $15^{\circ} \mathrm{C}$ post-stratification incubation temperature was selected on basis of the results of a companion study on the influence of temperature on bitterbrush germination and on

\section{Soil Matric Potential}

We used a 15-bar, ceramic plate, soilmoisture extractor to obtain soil-matric potentials of $-4,-6,-8$, and -12 bars in fine sand and clay soils. After the soils reached the desired equilibrium in the extractors, they were transferred to plastic $\mathrm{cm}$ deep in the firmly packed soil and sealed the boxes. The boxes were weighed at the beginning and end of stratification to determine if moisture was lost. The boxed 10 and seeds were stratified at 2 or $5^{\circ} \mathrm{C}$ for the soils were carefully moistened to ner saturation, and the opened boxes were incubated at $15^{\circ} \mathrm{C}$. Emerging seedling were counted weekly through 4 weeks, then the remaining seeds were dug up and checked for germination.

Table 1. Sources of bitterbrush seed used in stratification experiments.

\begin{tabular}{llccc}
\hline \hline Location & Community & $\begin{array}{c}\text { Elevation } \\
(\mathrm{m})\end{array}$ & \multicolumn{1}{c}{ Soil } & $\begin{array}{c}\text { Annual } \\
\text { precipitation } \\
(\mathrm{mm})\end{array}$ \\
\hline Truckee, Calif. & $\begin{array}{l}\text { Jeffrey pine/ } \\
\text { bitterbrush }\end{array}$ & 1,820 & Glacial till from granite and basalt & 500 \\
$\begin{array}{l}\text { Granite Peak, } \\
\text { Nev. }\end{array}$ & $\begin{array}{l}\text { Big sagebrush/ } \\
\text { bitterbrush }\end{array}$ & 1,760 & $\begin{array}{l}\text { Residual soil from decomposing quartz } \\
\text { diorite }\end{array}$ & 250 \\
Commercial & Unknown & - & & -
\end{tabular}

\section{Stratification-Temperature and Duration}

We composited the results from the 6 tests, two locations for 2 years, and two commercial sources. At specific temperatures and times, the sources showed significant differences, but the means and ranges of the six sources

\section{Results and Discussion}



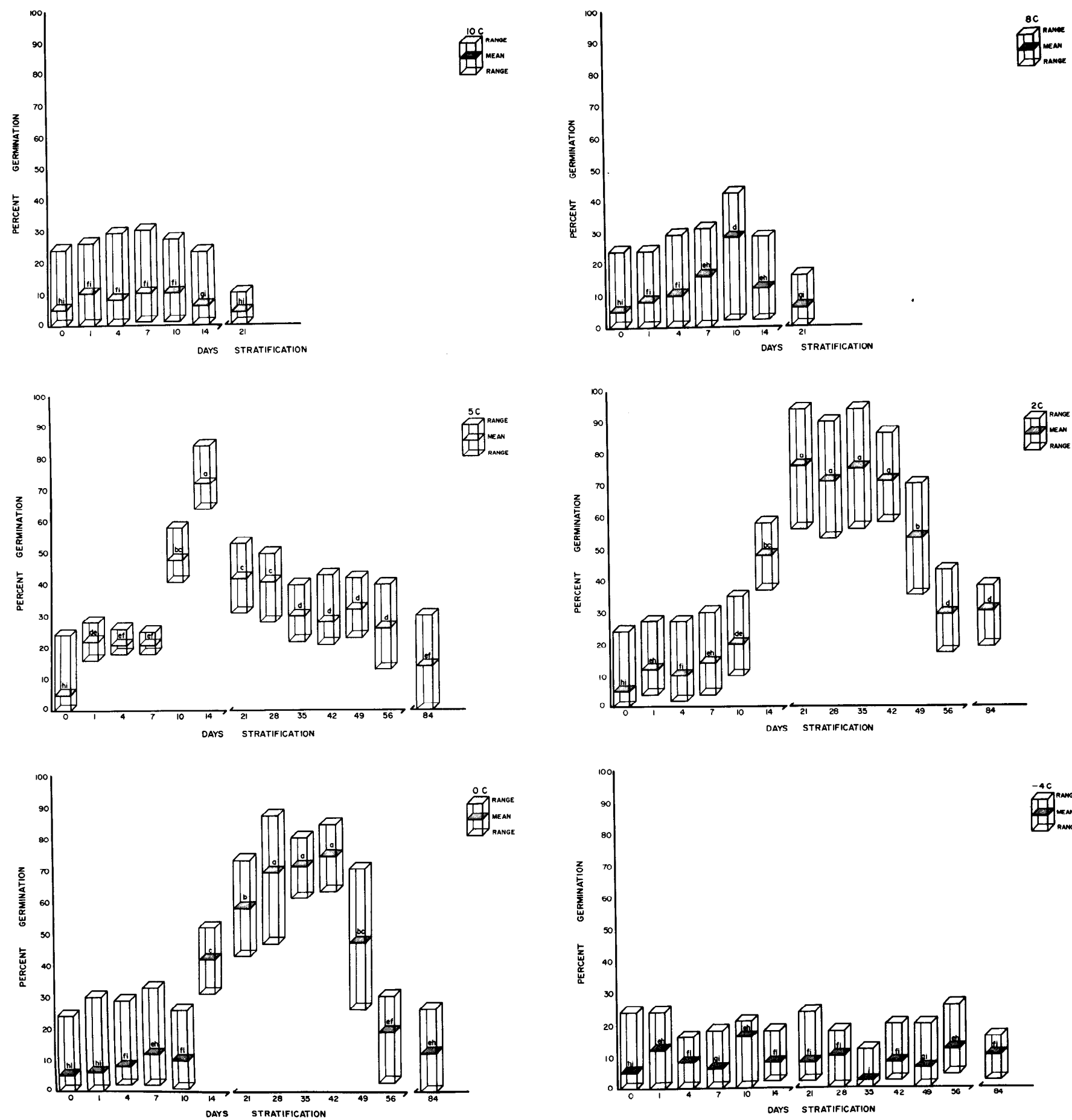

Fig. 1. Germination (mean and range) of six lots of bitterbrush seed incubated at $15^{\circ} \mathrm{C}$ after stratification at temperatures of $-4,0,2,5,8$, and $10^{\circ} \mathrm{C}$, from 0 through 84 days. No germination was observed in seed stratified longer than 21 days at 8 and $10^{\circ} \mathrm{C}$. Means (bars) with the same letter are not significantly different at the 0.01 level of probability as determined by Duncan's multiple range test.

(Fig. 1) provided a relatively precise indication of the response of bitterbrush seeds to stratification time and temperature.

Stratification at $10^{\circ} \mathrm{C}$ did not enhance subsequent germination after incubation at $15^{\circ} \mathrm{C}$. Germination was reduced because some bitterbrush seeds germinated when stratified at $10^{\circ} \mathrm{C}(\mathrm{Ta}-$ ble 2).

Reducing the stratification temperature to $8^{\circ} \mathrm{C}$ significantly $(P=0.01)$ increased subsequent germination at $15^{\circ} \mathrm{C}$ in 10 days. Continued stratification did not increase subsequent germination, because some seeds germinated during stratification (Table 2), and stratification requirements were not fully satisfied for the remainng seeds.

Stratification requirements were fully satisfied by 2 weeks at $5^{\circ} \mathrm{C}$. Longer periods of stratification sharply reduced germination. Part of this reduced 
germination was caused by germination during stratification, but losses due to microbial rot were more important. Bitterbrush seeds with stratification requirements satisfied were very susceptible to pathogens. The entire contents of the seed coat became liquified. Fungal mycelia were not always apparent.

The usual rcommended stratification for bitterbrush is 2- to 3-months (Forest Service, 1948). Petzold (as cited by Deitschman et al., 1974) found that short stratification periods of as little as 2 weeks gave adequate germination.

Reducing the temperature to $2^{\circ} \mathrm{C}$ extended the time of stratification necessary to produce optimum germination at $15^{\circ} \mathrm{C}$ from 1 to 4 weeks (Fig. 1). Stratification longer than 6 weeks at 1 $2^{\circ} \mathrm{C}$ reduced subsequent germination. About $5 \%$ of this reduction was due to germination during stratification (Table 2). The remainder was again due to decay of seeds. After 12 weeks of stratification at $2^{\circ} \mathrm{C}$ subsequent germination was still markedly better than it was with unstratified seeds, but it was much lower than the optimum.

Optimum germination with $0^{\circ} \mathrm{C}$ stratification did not occur until the fourth week; after 6 weeks, subsequent germination dropped. Subsequent germination after 9 and 12 weeks stratification was greatly lowered. These seeds did not rot, but the radicle tips were black when they started to emerge.

Continuous incubation at -2 or $-4^{\circ} \mathrm{C}$ did not markedly enhance subsequent germination (data for -2 not shown). Seeds that germinated after 12 weeks at $-4^{\circ} \mathrm{C}$ produced seedlings with normal radicles. Rate of subsequent germination at $15^{\circ} \mathrm{C}$ was the same as that for unstratified seeds.

Stratification of bitterbrush is intricately related to temperature and time. Hormay (1943) reported that the stratification requirements for bitterbrush seeds were 5 to 8 weeks at 0 to $5^{\circ} \mathrm{C}$. This temperature range is supported by

Table 3. Germination (\%) of bitterbrush seeds with 4 weeks incubation at $15^{\circ} \mathrm{C}$ after stratification with 0 to -12 bars osmotic potential at 2 or $5^{\circ} \mathrm{C}$ for 10 or 14 days. ${ }^{a}$

\begin{tabular}{cccccccc}
\hline & Duration & \multicolumn{7}{c}{ Osmotic potential (bars) } & Nonstratified \\
\cline { 2 - 7 } Temperature & days & 0 & -4 & -6 & -8 & -12 & seed \\
\hline 2 & 10 & $52 \mathrm{c}$ & $10 \mathrm{~d}-\mathrm{h}$ & $0 \mathrm{~b}$ & $12 \mathrm{~d}-\mathrm{h}$ & $0 \mathrm{~h}$ & $22 \mathrm{~d}$ \\
& 14 & $68 \mathrm{ab}$ & $16 \mathrm{~d}-\mathrm{g}$ & $8 \mathrm{~d}-\mathrm{h}$ & $10 \mathrm{~d}-\mathrm{h}$ & $4 \mathrm{c}-\mathrm{h}$ & $22 \mathrm{~d}$ \\
5 & 10 & $56 \mathrm{bc}$ & $20 \mathrm{~d}-\mathrm{f}$ & $6 \mathrm{e}-\mathrm{h}$ & $6 \mathrm{e}-\mathrm{h}$ & $10 \mathrm{~d}-\mathrm{h}$ & $22 \mathrm{~d}$ \\
& 14 & $80 \mathrm{a}$ & $12 \mathrm{~d}-\mathrm{h}$ & $16 \mathrm{~d}-\mathrm{g}$ & $18 \mathrm{~d}-\mathrm{f}$ & $2 \mathrm{gh}$ & $22 \mathrm{~d}$ \\
\hline
\end{tabular}

aMeans followed by the same letter are not significantly different at the 0.01 level of probability, as determined by Duncan's multiple range test.

our investigation, but our results indicate that the duration can be shortened. More important, excessively long stratification can reduce subsequent germination.

\section{Mode of Action \\ of Stratification}

Embryos require very little oxygen $\left(\mathrm{O}_{2}\right)$ in the environment to germinate. The lower the temperature, the less $\mathrm{O}_{2}$ is needed (Come and Tissaoui, 1972). After imbibition, the embryo receives dissolved $\mathrm{O}_{2}$ from water that the seed coat imbibes. However, the seed coat of many species of Rosaceae contains phenolic constituents that fix part of the dissolved $\mathrm{O}_{2}$ by oxidation and lower the quantity available to the embryo for other purposes (Come, 1967). The higher the temperature, the greater the $\mathrm{O}_{2}$ requirement of the embryo, but the quantity of available $\mathrm{O}_{2}$ decreases because at higher temperatures it is less soluble and phenolic substances fix more of it. At $2^{\circ} \mathrm{C}$, about $14 \mathrm{ppm} \mathrm{O}_{2}$ are soluble in water, but only $10 \mathrm{ppm}$ are soluble at $15^{\circ} \mathrm{C}$ (Streeter, 1935). Because low temperatures increase solubility of $\mathrm{O}_{2}$ in water and reduce both the requirements for it and the fixing capability of the seedcoat, stratification enhances germination of bitterbrush seeds.

\section{Osmotic Stress}

Lowered osmotic potentials significantly affected stratification and sub- sequent germination of bitterbrush (Table 3). This may have resulted from reduced oxygen availability in the osmotic solution, although polyethylene glycol is relatively stable when exposed to air.

\section{Matric Potential}

Moist sand was an excellent stratification material that produced subsequent germination of bitterbrush seeds comparable to those obtained with moist blotter paper (Table 4, Fig. 1). Slightly dry ( -4 bars) sand was not a satisfactory stratification material (Table 4). Clay, with its greater waterholding capacity, provided a marginal stratification environment at -4 bars, but was unsatisfactory at lower matric potentials.

\section{Stratification in the Field}

These results suggest that an ideal field stratification environment for bitterbrush would be one wth constant moisture near field capacity and a temperature regime of 0 to $5^{\circ} \mathrm{C}$. A continuous midwinter snow cover may create such an environment (Nord, 1965). Unfortunately, many critical winter ranges for big-game animals are at lower elevations with intermittent snow cover, in which soil moisture may not be continuously at optimum levels. Seedbed temperature may be above $5^{\circ} \mathrm{C}$ or below $0^{\circ} \mathrm{C}$.

Land managers probably are taking a large risk by spring seeding non-

Table 4. Germination (\%) of bitterbrush seeds with 4 weeks incubation at $15^{\circ} \mathrm{C}$ after stratification in sand or clay at 0 to -12 bars matric potential at 2 or $5^{\circ} \mathrm{C}$ for 10 or 14 days. ${ }^{a}$

\begin{tabular}{|c|c|c|c|c|c|c|c|c|c|c|c|c|}
\hline \multirow{3}{*}{$\begin{array}{c}\text { Temperature } \\
{ }^{\circ} \mathrm{C}\end{array}$} & \multirow{3}{*}{$\begin{array}{c}\text { Duration } \\
\text { days }\end{array}$} & \multicolumn{10}{|c|}{ Matric potential (bars) } & \multirow{3}{*}{$\begin{array}{c}\text { Nonstratified } \\
\text { seed }\end{array}$} \\
\hline & & \multicolumn{5}{|c|}{ Sand } & \multicolumn{5}{|c|}{ Clay } & \\
\hline & & 0 & -4 & -6 & -8 & -12 & 0 & -4 & -6 & -8 & -12 & \\
\hline 2 & $\begin{array}{l}10 \\
14\end{array}$ & $\begin{array}{l}48 \mathrm{~cd} \\
72 \mathrm{ab}\end{array}$ & $\begin{array}{l}20 \mathrm{gh} \\
14 \mathrm{~h}\end{array}$ & $\begin{array}{l}14 \mathrm{~h} \\
18 \mathrm{gh}\end{array}$ & $\begin{array}{l}16 \mathrm{~h} \\
20 \mathrm{gh}\end{array}$ & $\begin{array}{l}20 \mathrm{gh} \\
18 \mathrm{gh}\end{array}$ & $\begin{array}{l}44 \mathrm{~cd} \\
70 \mathrm{ab}\end{array}$ & $\begin{array}{l}38 \mathrm{de} \\
62 \mathrm{bc}\end{array}$ & $\begin{array}{l}22 \mathrm{gh} \\
16 \mathrm{~h}\end{array}$ & $\begin{array}{l}18 \mathrm{gh} \\
20 \mathrm{gh}\end{array}$ & $\begin{array}{l}16 \mathrm{~h} \\
24 \mathrm{f}-\mathrm{h}\end{array}$ & $\begin{array}{l}22 \mathrm{gh} \\
22 \mathrm{gh}\end{array}$ \\
\hline 5 & $\begin{array}{l}10 \\
14\end{array}$ & $\begin{array}{l}52 \mathrm{~cd} \\
76 \mathrm{ab}\end{array}$ & $\begin{array}{l}16 \mathrm{~h} \\
18 \mathrm{gh}\end{array}$ & $\begin{array}{l}20 \mathrm{gh} \\
24 \mathrm{f}-\mathrm{h}\end{array}$ & $\begin{array}{l}12 \mathrm{~h} \\
18 \mathrm{gh}\end{array}$ & $\begin{array}{l}24 \mathrm{f}-\mathrm{h} \\
20 \mathrm{gh}\end{array}$ & $\begin{array}{l}52 \mathrm{~cd} \\
78 \mathrm{a}\end{array}$ & $\begin{array}{l}42 \mathrm{de} \\
70 \mathrm{ab}\end{array}$ & $\begin{array}{l}32 \mathrm{e}-\mathrm{g} \\
22 \mathrm{gh}\end{array}$ & $\begin{array}{l}24 \\
12 \mathrm{~h}\end{array}$ & $\begin{array}{l}21 \mathrm{gh} \\
25 \mathrm{f}-\mathrm{h}\end{array}$ & $\begin{array}{l}22 \mathrm{gh} \\
22 \mathrm{gh}\end{array}$ \\
\hline
\end{tabular}

a Means followed by the same letter are not significantly different at the 0.01 level of probability as determined by Duncan's multiple range test. 
thiourea-treated bitterbrush seed. If conditions are optimum in the seedbed, stratification requirements can be satisfied in as little as 2 weeks. However, any departure from optimum temperature and moisture regimes will prolong the required duration of stratification or negate the effect of stratification.

\section{Literature Cited}

Come, D. 1967. L'inhibition de germination des graines de Pommier (Pirus malus L.) non dormantes. Role possible des phenols tegumentaltes, Ann. Sci. Natur., Bot. and Biol. Veg. 8:371-478.

Come, D., and T. Tissaoui. 1972. Interrelated effects of imbibition, temperature, and oxygen in seed germination. p. 157-168. In: W. Heydecker (Ed.). Seed Ecology. Pennsylvania State Univ. Press.

Deitschman, G. H., K. R. Jorgensen, and A. P. Plummer. 1974. Purshia. p. 686-688. In: C. S. Schopmeyer (Tech. Coor.). Seeds of Woody Plants in the United States. Forest Serv., U.S. Dep. Agr., Washington, D.C.

Evans, R. A., J. A. Young, R. Henkel, and G. J. Klomp. 1970. A low temperature gradient bar for seed germination studies. Weed Sci. 18:575-576.

Forest Service. 1948. Woody-plant seed manual I IS Den Agr.. Misc. Pub. 654. 416 p.
Hormay, A. L. 1943. Bitterbrush in Caifornia. California Forest and Range Exp. Sta., U.S. Forest Serv. Res. Note 39. 13 p.

Hubbard, R. L., and B. O. Pearson. 1958. Germination of thiourea-treated bitterbrush (Purshia tridentata) seed in the field. U.S. Dep. Agr., Forest Serv., California Forest and Range Exp. Sta. Forest Res. Note 138.6p.

Mirov, N. T., and C. J. Kraebel. 1937. Collecting and propagating the seeds of California wild plants. U.S. Dep. Agr., Forest Serv., California Forest and Range Exp. Sta. Res. Note 18. $27 \mathrm{p}$.

Nord, E. C. 1965. Autecology of bitterbrush in California. Ecol. Monogr. 35:307-334.

Nord, E. C., and B. Knowles. 1958. Rice hulls improve drilling of bitterbrush seed. California Forest and Range Exp. Sta., U.S. Forest Serv. Res. Note 134. 5 p.

Pearson, B. O. 1957. Bitterbrush (Purshia tridentata) seed dormancy broken with thiourea. J. Range Manage. 10:41-42.

Streeter, H. W. 1935. Stream pollution. Sewage Works J. 7:335.

Young, J. A., R. A. Evans, R. O. Gifford, and R. E. Eckert, Jr. 1970. Germination characteristics of three species of Cruciferae. Weed Sci. 18:41-48.

Young, J. A., R. A. Evans, R. O. Gifford, and R. E. Eckert, Jr. 1968. Germination of medusahead in response to osmotic stress. Weed Sci. 16:364-368.

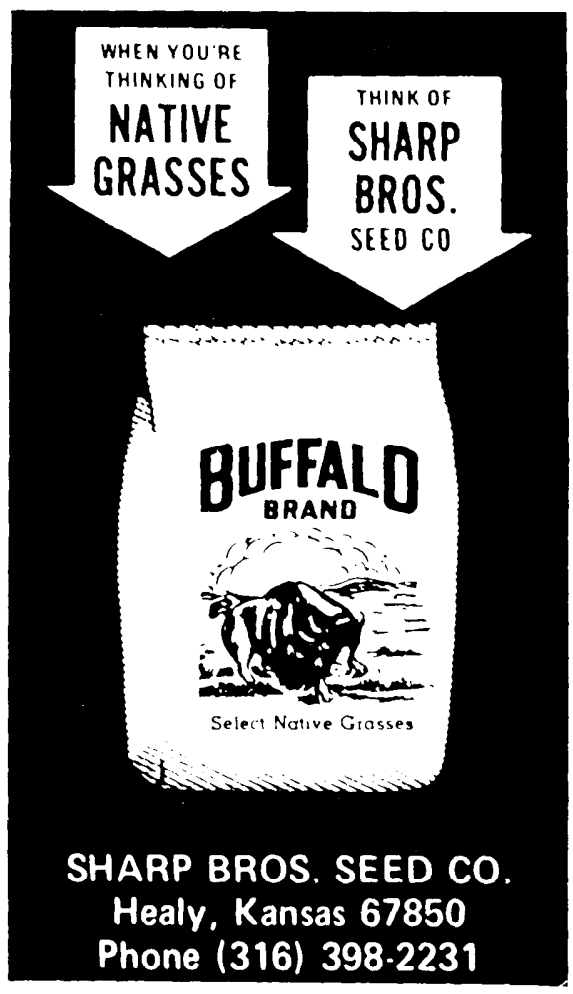

